\title{
ilkokul Öğrencilerinin Sosyal Problem Çözme Becerilerinin Çeşitli Değişkenler Açısından İncelenmesi ${ }^{*}$
}

\section{The Examination of Primary School Students' Social Problem-Solving Skills in Terms of Several Variables}

\section{Ebru UZUNKOL ${ }^{* *}$}

\section{Elif ÖZDEMIR YILMAZ***}

Öz. Bu araştırmada, ilkokul öğrencilerinin sosyal problem çözme becerilerinin çeşitli değişkenler açısından incelenmesi amaçlanmıştır. Bu amaçla, ilkokul öğrencilerinin sosyal problem çözme becerilerinin cinsiyet, sınıf düzeyi ve öğrenim gördükleri okulların konumuna göre farklılaşıp farklılaşmadığ incelenmiştir. Araştırmanın evrenini 2016-2017 eğitim-öğretim yılında Kocael İline bağlı İzmit Merkez İlçesi ve Körfez İlçesindeki okullarda öğrenim görmekte olan ilkokul 3. ve 4. sınıf öğrencileri oluşturmaktadır. Araştırmanın örneklemini ise oransız tabakalı örnekleme yolu ile tesadüfî olarak seçilen 469 öğrenci oluşturmaktadır. Araştırmada betimsel tarama modeli kullanılmıştır. Veriler "Sosyal Problem Çözme Becerileri Ölçeği" (Uzunkol ve Yel, 2016) aracılığı ile toplanmıştır. Veriler normal dağılım göstermediği için verilerin analizinde nonparametrik testlerden Mann-Whitney $U$ ve Kruskal-Wallis $H$ testleri kullanılmıştır. Yürütülen veri analizi çalışmaları sonucunda, ilkokul 3. ve 4. Sınıf öğrencilerinin sosyal problem çözme becerilerinin sınıf düzeyine ve öğrenim gördükleri okulun konumuna göre anlamlı bir farklıık gösterdiği; fakat cinsiyete göre anlamlı bir farklılık göstermediği bulgusu elde edilmiştir.

Anahtar Kelimeler: îlkokul, ilkokul öğrencisi, sosyal problem çözme.

\begin{abstract}
The aim of the study is to examine the divergence of the primary school students' social problem solving skills according to the variables of gender, class level, and the location of the school where they receive education. The population of the study consists of primary school students who are studying in 3rd and 4rd year during the fall semester of 2016-2017 in Province İzmit Central District and Körfez District. The sample is composed of 469 students. Descriptive survey model has been used in the study. The study data was collected with "Social Problem Solving Skills Scale". Mann-Whitney U and Kruskal-Wallis $\mathrm{H}$ tests were used in data analysis. According to the findings while there was no significant difference in the children's social problem-solving skills compared to the gender variable, there was a significant difference according to class level and the location of the school where they receive education.
\end{abstract}

Keywords: Primary school, primary school student, social problem solving.

\section{Toplumsal Mesaj.}

$\mathrm{Bu}$ araştırmanın amacı, ilkokul öğrencilerinin sosyal problem çözme becerilerinin çeşitli değişkenler açısından incelenmesidir. Araştırmadan elde edilen bulgular, ilkokul öğrencilerinin sosyal problem çözme becerilerinin cinsiyete göre farklılaşmadığı; fakat sınıf düzeyi ve öğrenim görülen okulun konumuna göre farklılaştığını ortaya koymaktadır.

Public Interest Statement. In this study, social problem solving skills of primary school students were examined in terms of various variables. As a result, it was concluded that the social problem-solving skills did not differ according to gender. But there was a significant difference according to class level and the location of the school where they receive education.

\footnotetext{
* Bu çalışmadan elde edilen bulguların bir kısmı 16. Uluslararası Sınıf Öğretmenliği Eğitimi Sempozyumunda sözlü bildiri olarak sunulmuştur.

** Orcid ID:http://orcid.org/0000-0002-1897-137X, Dr. Öğr. Üyesi, Sakarya Üniversitesi, Eğitim Fakültesi, Sınıf Eğitimi Anabilim Dalı, ebrud@sakarya.edu.tr

*** Orcid ID:http://orcid.org/0000-0003-1490-9701, Sakarya Üniversitesi Eğitim Bilimleri Enstitüsü Yüksek Lisans Öğrencisi, elif.yilmaz23@ogr.sakarya.edu.tr
} 


\section{GiRiş}

Eğitim çağın gerektirdiği niteliklere sahip insanları yetiştirmenin önemli araçlarından biridir. Okullar aracılığıyla verilen eğitim ile yaşanılan çağda intiyaç duyulan özelliklere sahip bireyler yetiştirilir. Bu bireyler bir taraftan yaşadıkları toplumun kültürünün aktarıldığı yeni nesil olarak önem kazanırken, diğer yandan toplumu daha ileriye taşıyacak umut kuşağı olarak değer görürler. Toplumların intiyaç duyduğu insan modeli ise çağdan çağa değişiklik gösterebilmektedir. Bilgi çağı ile birlikte dünyada bilgiye ulaşmayı bilen, eleştirel bir bakış açısına sahip, kendini yenilemeye açık ve çevresiyle sağlıklı iletişim kurabilen bireylere duyulan intiyaç artmıştır. Birlikte çalışabilmek ve yaşayabilmek konusundaki beceriler ise her geçen yıl önem kazanmaya devam etmiştir.

Insanların bir arada yaşarken birbirleriyle anlaşmazlık ve çatışmalar yaşaması kaçınılmaz olmakla birlikte, bu aşamada yaşanan sorunlarından uygun yollarla üstesinden gelebilmek önem kazanmaktadır. Anlıak ve Dinçer (2005), söz konusu güçlükleri aşabilmek için incelik isteyen davranış ve düşünme becerilerine sahip olmak gerektiğini, dolayısıyla sosyal problem çözme becerisinin çok erken yaşlarda desteklenmesi gereken ve yaşam boyu süren becerilerden biri olarak kabul edildiğini belirtmektedir. Çünkü insanların diğer bireylerle kurduğu iletişimin şekli sosyal ilişkilerimizin en önemli belirleyicilerinden biridir ve bu süreçte bazı sorunlarla karşılaşılması olağandır. Karşılaşılan sorunlarla baş edebilme ve üstesinden gelebilme becerisi, bunun için benimsenen tarz, insanın sosyal yaşamının önemli belirleyicilerinden birisi olarak karşımıza çıkmaktadır (Uzunkol,2014). Bu noktada kişilerin problem çözme becerileri devreye girmektedir. Korkut (2002: 177) problem çözmeyi, karşılaşılan bir sorunu çözmek için önceki yaşantılar yolu ile öğrenilmiş kuralların uygulanmasından farkı olarak, yeni çözüm yolları bulabilme olarak tanımlamaktadır. Sosyal problem çözme ise problemli bir durumla baş edebilmek için, bağımsız bir şekilde etkili ve uygulanabilir çözüm alternatifleri oluşturma ve oluşturulan alternatiflerden en uygun olacağı düşünülen birini seçmeyi kapsayan bilişsel ve davranışsal bir süreçtir (D'Zurilla ve Golfried, 1971; D'Zurilla ve Nezu, 1982; Kayılı ve Arı, 2015).

Pek çok becerinin kazanımında olduğu gibi, sosyal problem çözme becerisinin kazanımasında da çocukluk döneminin kritik bir öneme sahip olduğu düşünülmektedir. Çocukluk dönemi olarak adlandırılan bu dönem, bir araştırma ve keşfetme sürecini kapsamaktadır. Çocukluk döneminde elde edilen yaşantılar, çocuğun sosyal gelişiminin temelini oluşturmaktadır. Sağıkıı bir sosyal gelişim için ise bazı temel becerilerin kazanılması gerekmektedir. Bu temel becerilerden biri de, toplumsal yaşam için son derece önemli bir rol oynayan sosyal problem çözmedir (Anooshian, Pascal ve McCreath, 1984; Arı ve Şahin Seçer, 2003). Orta çocukluk dönemi olarak adlandırılan ve 711 yaş arasını kapsayan bu dönemde çocuklar aileleri dışındaki bireylerle iletişim kurarak sosyalleşmektedirler ve tıpkı yetişkinler gibi akranlarıyla sorunlar ve çatışmalar yaşamaktadırlar. Bu dönemde çocuklar için akran grupları gelişim için önemi giderek artan bir bağlam halini almaktadır (Berk, 2013). Sosyal alanlarının genişlemesi de yaşadıkları problemlerin çeşitlenmesine neden olmaktadır. Çocukların bu çatışmaların çözümü için belirlemiş oldukları yaklaşımları ilerleyen yıllarda da sürdürmeleri olasıdır. Bu sebeple çocukların sosyal problem çözme becerileri hem çocuğun sosyal-duygusal gelişimi açısından hem de sağlıklı bir toplumsal yaşam açısından oldukça önemli görülmektedir. Nitekim sosyal problem çözme becerileri ile ilgili yapılan araştırmalar da sosyal anlamda yaşadıkları problemleri etkili bir biçimde çözememenin çocuklarda; depresyon, anksiyete (Levendosky, Okun ve Parker, 1995), agresiflik (Takahashi, Koseki ve Shimada, 2009) gibi olumsuz durumlarla ilişkili olduğunu ortaya koymaktadır.

Çocuklarda sosyal problem çözme becerilerinin gelişim aşamalarına ilişkin yürüttükleri araştırmalar sonucunda araştırmacılar sosyal problem çözme becerisinin gelişimine ilişkin farklı modeller ortaya koymuşlardır (Uzunkol, 2014). Spivack, Platt ve Shure (1976), sosyal problem çözme ekseninde "kişilerarası bilişsel problem çözme" modelini geliştirmişlerdir. Buna göre ilk basamakta, çocuklardan karşılaşılan probleme ilişkin alternatif çözümler üretmeleri beklenmektedir. i̇kinci ve üçüncü basamakta, söz konusu çözüm önerilerinin etkilerinin ve uygulanması halinde hangi sonuçlara yol açacağının düşünülmesi gerekmektedir. Dördüncü basamak ise bu tür problemlere 
karşı duyarlııktır. Burada çocuklardan davranışlarının kişiler üzerindeki etkilerini fark ederek sorunları çözmeleri beklenmektedir. Son basamak olan perspektif alma ise, tepkilerin olayların özelliklerine göre değişebilir olduğunu ve farklı düşüncelerin de var olduğunu anlamalarına işaret etmektedir (Spivack, Platt ve Shure, 1976, Akt. Stevens, 2009: 20-21). Warden ve McKinnon (2003) ise sosyal problem çözme becerisini problem durumuna ilişkin olarak alternatif çözümler üretme, çözümlerden birini seçme ve seçimin sonuçlarını değerlendirme olmak üzere üç basamak altında değerlendirmişlerdir.

Sosyal problem çözme sürecinde ilk basamak olan alternatif çözümler üretme aşamasında düşüncelerin belirli bir kısıtlama olmadan, problemin çözümüne yönelik önerilerin ortaya koyulmasından oluşur. Sonraki aşamalardan olan seçim aşamasında ise uygulanmak amacıyla seçilen çözümün niteliği önem kazanmakta (Ögülmüş, 2006) ve bu basamak sosyal problem çözme becerisi açısından oldukça kritik bir öneme sahiptir. Lochman, Lampron ve Rabiner, (1989), çocukların seçtikleri çözümleri sözlü beyan, direktçözüm, yardım istemek ve sözel veya fiziksel saldırganlık olmak üzere dört başlık altında sınıflandırmıştır. Warden ve MacKinnon (2003) ise bazı basamaklar benzer olmakla birlikte bir basamak daha ekleyerek sosyal problem çözme becerisini beş farkıı basamakta incelemişlerdir. illk basamak, "doğrudan çözüm" şeklinde adlandırımaktadır. Doğrudan çözüm yolunu benimseyen çocuklar, problemi bağımsız bir şekilde, beklenen yaklaşımlar (karşısındakine davranışın sebebini sorma veya başka teklifler sunma vb.) kullanarak çözmeye odaklanırlar. İkinci basamak "dolaylı çözüm" olarak adlandırıımıştır ve daha çok başkalarından yardım isteme gibi çözüm yolunun aracı kullanılarak çözüldüğg̈ ve sürecin uzatıldığı durumları ifade eder. Üçüncü basamak "pasif çözüm" basamağıdır. Pasif çözümü tercih eden çocuklar, problemden kaçınmaya veya görmezden gelmeye eğilimlidirler. Son basamak olan "Agresif çözüm" basamağı ise, problemin sözel veya fiziksel saldırganlık aracılığılla (küfür etme, vurma vb.) çözülmesini ifade etmektedir. Çocukların ifade etmiş olduğu çözümler problemle bağlantılı değil ise ve anlaşılamıyor ise bu çözümler son basamak olan "belirsiz çözüm" başlığı altında değerlendirilmektedir.

Sosyal problem çözme becerilerine ilişkin yapılmış araştırmalar incelendiğinde, sosyal problem çözme becerisinin farklı değişkenlerle ilişkisinin ortaya koyulduğu ve sosyal problem çözme becerilerinin artırımasına yönelik deneysel çalışmalar yürütüldüğü de görülmektedir. Walker ve Henderson (2012) çocukları hem okul öncesi dönemde hem de birinci sınıfta izleyerek yürüttükleri çalışmalarında sosyal problem çözme becerilerinin akademik başarı üzerinde dolaylı olarak etkili olduğunu ortaya koymuştur. Bu çalışmalarında Walker ve Henderson (2012) sosyal problem çözme becerilerinin erken dönemde geliştirilmesinin okul başarısı ve okul uyumu konusunda ileriye dönük yaşanacak sıkıntıları önleyici bir etki göstereceğini belirtmişlerdir. Basun (2017) ise 48-66 ay arası çocuklar ile yürüttüğü çalışmasında kentte yaşayan çocukların kırsalda yaşayan çocuklara göre ve kızların erkeklere göre sosyal problem çözme becerilerinin daha yüksek olduğu sonucuna ulaşmıştır. Sosyal problem çözme becerileri ile ilgili yapılan farklı çalışmaların sonuçları da sosyal problem çözme becerisinin cinsiyet (Arı ve Yaban, 2012; Walker, Irwing ve Berthelsen, 2002), ailelerin çocuklara yönelik tutumları (Karakuş, 2017), iyi hissetme (Chang, D'Zurilla ve Sanna, 2009; Siu ve Shek, 2010) ve öfke (Takahaski, Koseki ve Shimada, 2009) gibi değişkenlerle ilişkili olduğunu göstermektedir. Bununla birlikte sosyal problem çözme becerilerininin geliştirilmesine yönelik deneysel çalışmalar da bulunmaktadır. Örneğin Topçu Kabasakal, Sağkal ve Türnüklü (2015), çalışmalarında barış eğitimi programının dokuzuncu sınıf öğrencilerinin şiddet eğilimi ve sosyal sorun çözme becerisi üzerindeki etkisini araştırmışlardır. Sonuç olarak, söz konusu programa dâhil edilen deney grubundaki öğrencilerin sosyal problem çözme becerilerinin artığı, şiddet eğilimlerinin ise azaldığı bulgusunu elde etmişlerdir. Benzer olarak Kayılı (2015) çalışmasında sosyal beceri eğitimi programına katılan çocukların sosyal problem çözme becerisi düzeylerinin arttı̆̆ı sonucuna ulaşmıştır. Çalışma sonuçları göstermektedir ki sosyal problem çözme becerileri bazı değişkenlerle ilişki olmakla birlikte yapılan bir takım uygulamalar ile geliştirilebilmektedir. 
Aileler çocuklarının çevresindeki bireylerle pozitif ilişkiler kurabilmesini, akranlarıyla gerek okulda gerekse diğer sosyal gruplarla uyum içinde olmasını, gelecekte kendilerini tehlikelerden korumalarını sağlayacak otokontrole ve motivasyona sahip olmalarını isterler (Özaydın, 2006). Öğretmenler ve okul yönetimleri de çocukların birbirleriyle olan sorunlarını uygun stratejilerle ve şiddet içermeden çözmesine yönelik çaba sağlarlar. Bu bakımdan temel eğitim ve elbette ilkokul dönemi kritik bir öneme sahiptir. Bu çalışmada da, ilkokul 3. ve 4. sınıfta öğrenim görmekte olan çocukların sosyal problem çözme becerilerinin; cinsiyet, öğrenim görülen okulun bulunduğu konum (köy, ilçe, il merkezi) ve sınıf düzeyleri bakımından farklılaşıp farklılaşmadığının incelenmesi amaçlanmıştır. Sosyal problem çözme becerisi ile ilgili yapılan çalışmalar incelendiğinde ülkemizde bu konu ile ilgili yürütülen çalışmaların sayısında son yıllarda artış görüldüğü söylenebilir. Bununla birlikte yapılan çalışmaların büyük bir kısmının okul öncesi eğitim dönemini kapsadığını söylemek mümkündür (Bozkurt Yükçü ve Demircioğlu, 2017; Kayılı ve Arı, 2015; Özmen, 2013). Bu açıdan bakıldığında, kişisel ve sosyal gelişim açısından büyük öneme sahip olan orta çocukluk dönemindeki çocukların sosyal problem çözme becerilerinin farklı değişkenler açısından incelenmesinin, geliştirilmesi gereken yönlere ışık tutması beklenmektedir. Ayrıca çalışmanın hem ailelere hem de öğretmenlere sosyal problem çözme becerisinin değerlendirilmesi ile ilgili olarak yardımcı olması, sınıf öğretmenlerinin öğrencilerin uyumsuz davranışlarını anlamlandırmasına yardımcı olması ve anlamlandırma sonucunda da bu konudaki sorunların çözümüne yönelik farklı stratejiler ve yöntemler geliştirmelerine katkı sağlaması açısından da önemli görülmektedir.

\section{YÖNTEM}

Bu araştırma var olan bir durumu ortaya koymaya yönelik bir araştırma olduğundan betimsel tarama modeli kullanılmıştır. Betimsel tarama modeli, bir durumu var olduğu şekliyle tespit etmeyi amaçlayan; olay, birey ya da nesnelerin sahip oldukları koşullar içerisinde olduğu gibi tanımlanmaya çalışıldığı bir araştırma modelidir (Karasar, 2016).

\subsection{Evren-Örneklem}

Araştırmanın evrenini 2016-2017 eğitim-öğretim yılında Kocaeli ïline bağlı İzmit Merkez İlçesi (5217'si 3. sınıf, 4423'ü 4. sınıf) ve Körfez İlçesinde (3028'i 3. sınıf, 2634'ü 4. sınıf) öğrenim görmekte olan toplam 15.302 ilkokul 3. ve 4. sınıf öğrencisi oluşturmaktadır. Araştırmanın örneklemi oransız tabakalı örnekleme yolu ile seçilmiştir. Tabakalı örnekleme yöntemi evrende var olan alt tabakalar veya alt birimler olduğu durumlarda kullanılır (Yıldırım ve Şimşek, 2005). İlk olarak örneklem büyüklüğüne karar verilmiş, buna göre örneklem büyüklüğünün \%95 güven aralığında 383 olması gerektiği sonucuna ulaşıımıştır. Sınıf düzeyleri tabakalar olarak belirlenmiş ve her iki sınıf düzeyinden de tesadüfî olarak seçilen 480 ilkokul öğrencisine ulaşıımıştır. Ancak eksik bir şekilde veya anlaşılmaz bir şekilde doldurulan veriler ayıklanmış, 469 öğrenciden elde edilen veriler araştırmaya dâhil edilmiştir. Örnekleme dâhil olan öğrencilerin demografik özellikleri Tablo 1'de sunulmaktadır:

Tablo 1. Araştırmaya katılan öğrencilerin dağıımları

\begin{tabular}{|c|c|c|c|}
\hline & & $f$ & $\%$ \\
\hline \multirow{2}{*}{ Cinsiyet } & $\mathrm{KIz}$ & 237 & 50.5 \\
\hline & Erkek & 232 & 49.5 \\
\hline \multirow{3}{*}{ Sınıf Düzeyi } & 3.sinıf & 234 & 49.9 \\
\hline & 4.sinıf & 235 & 50.1 \\
\hline & ill Merkezi & 141 & 30.1 \\
\hline \multirow[t]{3}{*}{ Konum } & İlçe Merkezi & 188 & 40.1 \\
\hline & Köy & 140 & 29.8 \\
\hline & Toplam & 469 & 100.0 \\
\hline
\end{tabular}




\subsection{Veri Toplama Aracı}

Araştırmaya ilişkin veriler Uzunkol ve Yel (2016) tarafından geliştirilen "Sosyal Problem Çözme Becerileri Ölçeği" aracılı̆ı ile toplanmıştır. Sosyal Problem Çözme Becerileri Ölçeği, çocukların günlük yaşamlarında karşılaşma olasılıkları olan sorunları içeren üç kısa örnek olay, bu sorunlara ilişkin olarak üç soru ve sorulara verilen cevapların değerlendirildiği bir analitik derecelendirme ölçeğinden oluşmaktadır. Ölçeğin alternatif çözümler üretme, uygun çözüm seçme ve çözümün sonuçlarını kestirebilme olmak üzere üç farklı alt boyutu bulunmaktadır. Her bir örnek olaya ilişin sorulan sorular, söz konusu alt boyutlara ilişkin sorulardır. Alternatif çözümler üretme boyutunda, öğrencilerden örnek olaylarda yer alan sorunların çözümüne yönelik farklı çözüm önerileri sunmaları istenmektedir. Uygun çözüm seçme boyutunda, öğrencilerin bir önceki basamakta önerdikleri çözüm yollarından kendilerine göre en uygun olanını seçmeleri gerekmektedir. Öğrenci tarafından seçilmiş olan çözüm beş farklı ölçüte göre değerlendirilmektedir. Bunlar sırası ile belirsiz çözüm, agresif çözüm, kaçınmacı çözüm, dolaylı çözüm ve doğrudan çözüm şeklinde isimlendirilmektedirler. Herhangi bir çözümün sunulmadığı ya da problemle ilişkisiz bir çözüm sunulduğu durumlarda öğrencinin cevabı "belirsiz çözüm" kategorisi altında değerlendirilmekte ve öğrenci " 0 " puan almaktadır. Sözel veya fiziksel şiddet içeren çözüm sunulduğu durumlarda öğrencinin cevabı "agresif çözüm" kategorisi altında değerlendirilmekte ve öğrenci "1" puan almaktadır. Sorunun görmezden gelindiği ya da sorunun olduğu ortamdan uzaklaşmaya yönelik bir çözüm seçildi ise öğrencinin cevabı "kaçınmacı çözüm" kategorisi altında değerlendirilmekte ve öğrenci "2" puan almaktadır. Sonun çözümü için sorumluluğun anne, ağabey ya da bekçi gibi bir başkasına aktarıldığı durumlarda ise öğrencinin cevabı "dolaylı çözüm" kategorisi altında değerlendirilmekte ve öğrenci "3" puan almaktadır. Sorunun konuşularak ya da yapıcı bir şekilde çözülmesine ilişkin bir çözüm seçildiğinde ise öğrencinin cevabı "doğrudan çözüm" kategorisi altında değerlendirilmekte ve öğrenci en yüksek puan olan "4" puan almaktadır. Çözümün sonuçlarını kestirebilme boyutunda ise öğrencilerden, seçmiş oldukları çözümün hem uzun hem de kısa vadede yaratacağı olumlu ve olumsuz sonuçlarına ilişkin kestirimlerde bulunmaları beklenmektedir. Her bir boyuta ilişkin öğrenciler en az 0 en fazla 4 puan alabilmektedirler.

Sosyal problem çözme becerileri ölçeğinin geçerlik güvenirlik çalışmaları ilkokul 3. sınıf öğrencileri ile birlikte yürütülmüştür. Güvenirlik hesaplamalarında elde edilen güvenirlik katsayıları her bir boyut için için sırası ile $.78, .73$ ve .82 olarak hesaplanmıştır. Cronbach Alfa katsayısı hesaplamalarına ek olarak puanlayıcılar arası güvenirlik düzeyi hesaplanmıştır. Bu aşamada Pearson Korelasyon Katsayısından yararlanılmış ve puanlayıcılar arası güvenirlik düzeyleri sırasıyla $.97, .94$, ve .92 şeklinde hesaplanmıştır (Uzunkol, 2014). Bu araştırmaya dahil olan örneklem ilkokul 3 sınıf öğrencileri ile birlikte ilkokul 4. Sınıf öğrencilerini de kapsadığından, söz konusu örneklem üzerinde tekrar güvenirlik analizi çalışması yapılmıştır. Yapılan güvenirlik analizi sonucunda ise Cronbach Alfa iç tutarlık katsayılarının her üç boyutta da .73'ün üzerinde olduğu sonucuna ulaşılmıştır. Bununla birlikte puanlayıcılar arası güvenirliğin hesaplanması amacı ile 3. ve 4. sınıf düzeylerindeki veriler arasından ellişer veri seçilmiş, bu veriler her iki araştırmacı tarafından da değerlendirilmiştir. Her üç boyutta da Pearson Momentler Çarpımı Korelasyon katsayısının .92'nin üzerinde olduğu sonucuna ulaşılmıştır.

\subsection{Verilerin Analizi}

Verilerin analizi basamağında ilk olarak geçerli sayılamayacak veriler ayıklanmış ve sonuç olarak 469 veri analize dâhil edilmiştir. Ardından verilerin normal dağılıp dağılmadığı Kolmogorov-Smirnov testi kullanılarak kontrol edilmiş ve verilerin normal dağılım göstermediği sonucuna ulaşılmıştır $(p<.05)$. Veriler normal dağılım göstermediği için sosyal problem çözme becerilerinin cinsiyete ve sınıf düzeyine göre farklılaşma durumları Mann Whitney $U$ testi, okulun bulunduğu konuma göre farklılaşma durumları ise Kruskal-Wallis testi aracılığı ile incelenmiştir. Daha sonra tekrar Mann Whitney U testi yapılarak farklılıkların kaynakları tespit edilmiştir. 


\section{BULGULAR}

\subsection{Cinsiyete Göre Sosyal Problem Çözme Becerilerinin İncelenmesi}

illkokul 3. ve 4. sınıf öğrencilerinin sosyal problem çözme becerilerinin cinsiyete göre Mann Whitney-U Testi sonuçları Tablo 2'de gösterilmektedir:

Tablo 2. Cinsiyete göre sosyal problem çözme becerilerinin farklılaşma durumları

\begin{tabular}{llcccccc}
\hline & Gruplar & $\mathrm{n}$ & $\begin{array}{c}\text { Sıralar } \\
\text { Ortalaması }\end{array}$ & $\begin{array}{c}\text { Sıralar } \\
\text { Toplamı }\end{array}$ & M-Whitney U & $\mathrm{Z}$ & $\mathrm{p}$ \\
\hline $\begin{array}{l}\text { Alternatif } \\
\text { Çözümler }\end{array}$ & Kız & 237 & 227.95 & 54023.00 & & & \\
Üretme & Erkek & 232 & 242.21 & 56192.00 & 25820.00 & -1.145 & 0.252 \\
Uygun Çözüm & Kız & 237 & 246.63 & 58451.50 & & & \\
Seçme & Erkek & 232 & 223.12 & 51763.50 & 24735.00 & -1.895 & 0.058 \\
Çözümün & Kız & 237 & 240.36 & 56966.00 & & & \\
$\begin{array}{l}\text { Sonuçlarını } \\
\text { Kestirebilme }\end{array}$ & Erkek & 232 & 229.52 & 53249.00 & 26221.00 & -0.876 & 0.381 \\
& Toplam & 469 & & & & & \\
\hline
\end{tabular}

Tablo 2 incelendiğinde, ilkokul öğrencilerinin sosyal problem çözme becerilerinin üç boyutta da cinsiyete göre anlamlı bir farklııı göstermediği sonucuna ulaşılmıştır ( $p>.05$ ).

\subsection{Sınıf Düzeyine Göre Sosyal Problem Çözme Becerilerinin İncelenmesi}

İlkokul 3. ve 4. Sınıf öğrencilerinin sosyal problem çözme becerilerinin sınıf düzeyine göre göre Mann Whitney-U Testi sonuçları Tablo 3'te gösterilmektedir:

Tablo 3. Sınıf düzeyine göre sosyal problem çözme becerilerinin farklılaşma durumları

\begin{tabular}{lccccccc}
\hline & Gruplar & $\mathrm{n}$ & $\begin{array}{c}\text { Sıralar } \\
\text { Ortalaması }\end{array}$ & $\begin{array}{c}\text { Sıralar } \\
\text { Toplamı }\end{array}$ & M-Whitney U & Z & $\mathrm{p}$ \\
\hline $\begin{array}{l}\text { Alternatif } \\
\text { Çözümler }\end{array}$ & 3. sınıf & 234 & 248.29 & 58100.50 & & & \\
Üretme & 4. Sınıf & 235 & 221.76 & 52114.50 & 24384.50 & -2.129 & 0.033 \\
Uygun Çözüm & 3. sınıf & 234 & 218.20 & 51058.00 & & & \\
Seçme & 4. Sınıf & 235 & 251.73 & 59157.00 & 23563.00 & -2.702 & 0.007 \\
Çözümün & 3. sınıf & 234 & 221.09 & 51734.50 & & & \\
$\begin{array}{l}\text { Sonuçlarını } \\
\text { Kestirebilme }\end{array}$ & 4. Sınıf & 235 & 248.85 & 58480.50 & 24239.50 & -2.244 & 0.025 \\
\hline
\end{tabular}

Tablo 3 incelendiğinde, ilkokul öğrencilerinin sosyal problem çözme becerilerinin sınıf düzeyine göre üç boyutta da anlamlı bir farklııık gösterdiği sonucuna ulaşılmıştır $(p<.05)$. Buna göre alternatif çözümler üretme boyutunda 3. sınıf öğrencilerinin 4. sınıf öğrencilerine göre daha fazla sayıda alternatif çözüm ürettikleri görülmektedir. Bununla birlikte uygun çözüm seçme becerileri incelendiğinde ise 4. sınıf öğrencilerinin lehine bir farklılık olduğu, 4. sınıf öğrencilerinin 3. sınıf öğrencilerine göre daha nitelikli çözümler ürettiği bulgusu ortaya çıkmaktadır. Çözümün seçimlerini kestirebilme becerisi incelendiğinde yine 4. sınıf öğrencilerinin lehine bir farklılık olduğu sonucuna ulaşılımıştır.

\subsection{Okul Konumuna Göre Sosyal Problem Çözme Becerilerinin İncelenmesi}

İlkokul 3. ve 4. Sınıf öğrencilerinin sosyal problem çözme becerilerinin öğrenim görülen okulun bulunduğu konuma göre Kruskal-Wallis Testi sonuçları Tablo 4'te gösterilmektedir: 
Tablo 4. Öğrenim görülen okulun bulunduğu konuma göre sosyal problem çözme becerilerinin farklılaşma durumları

\begin{tabular}{|c|c|c|c|c|c|c|c|}
\hline & Gruplar & $\mathrm{n}$ & $\begin{array}{c}\text { Sıra } \\
\text { Ortalaması }\end{array}$ & sd & $x^{2}$ & $\mathrm{p}$ & Anlamlı Fark \\
\hline \multirow{3}{*}{$\begin{array}{l}\text { Alternatif } \\
\text { Çözümler } \\
\text { Üretme }\end{array}$} & Köy & 141 & 142.32 & \multirow{3}{*}{2} & \multirow{3}{*}{95.497} & \multirow{3}{*}{.000} & \multirow{3}{*}{$\begin{array}{l}\text { Köy- ill merkezi } \\
\text { Köy-ilıçe Merkezi }\end{array}$} \\
\hline & İlçe & 188 & 278.66 & & & & \\
\hline & İl merkezi & 140 & 269.71 & & & & \\
\hline \multirow{3}{*}{$\begin{array}{l}\text { Uygun Çözüm } \\
\text { Seçme }\end{array}$} & Köy & 141 & 186.05 & \multirow{3}{*}{2} & \multirow{3}{*}{28.997} & \multirow{3}{*}{.000} & \multirow{3}{*}{$\begin{array}{l}\text { Köy- İl merkezi } \\
\text { Köy-İlçe Merkez }\end{array}$} \\
\hline & İlçe & 188 & 246.47 & & & & \\
\hline & İl merkezi & 140 & 268.91 & & & & \\
\hline \multirow{4}{*}{$\begin{array}{l}\text { Çözümün } \\
\text { Sonuçlarını } \\
\text { Kestirebilme }\end{array}$} & Köy & 141 & 168.53 & \multirow{4}{*}{2} & \multirow{4}{*}{80.082} & \multirow{4}{*}{.000} & \multirow{4}{*}{$\begin{array}{l}\text { Köy- İl merkezi } \\
\text { Köy-İlçe Merkez }\end{array}$} \\
\hline & illçe & 188 & 233.81 & & & & \\
\hline & İl merkezi & 140 & 307.58 & & & & \\
\hline & Toplam & 469 & & & & & \\
\hline
\end{tabular}

Tablo 4 incelendiğinde, ilkokul öğrencilerinin sosyal problem çözme becerilerinde üç boyutta da anlamlı bir farklıık olduğu sonucuna ulaşılmaktadır (p>.05). Söz konusu farklıkların kaynakları incelendiğinde, alternatif çözüm üretme boyutunda il merkezi ve ilçe merkezinde öğrenim gören öğrencilerin köyde öğrenim gören öğrencilere göre daha fazla alternatif çözüm ürettiği görülmektedir. Uygun çözüm seçme becerileri boyutunda da il ve ilçe merkezinde öğrenim gören öğrencilerin köyde öğrenim gören öğrencilere göre nitelikli çözümler ürettiği sonucuna ulaşımıştır. Çözümün seçimlerini kestirebilme becerisi incelendiğinde yine il ve ilçe merkezinde yaşayan öğrencilerin lehine bir farklılık olduğu sonucuna ulaşıımıştır.

\section{SONUÇ VE TARTIŞMA}

Bu araştırmada, ilkokul öğrencilerinin sosyal problem çözme becerilerinin cinsiyete, sınıf düzeyine ve öğrenim görülen okulun konumuna göre incelenmesi amaçlanmıştır. Araştırma sonucunda ilkokul 3. ve 4. sınıf öğrencilerinin sosyal problem çözme becerilerinin cinsiyete göre bir farklılık göstermediği sonucuna ulaşılmıştır. Sosyal problem çözme becerilerinin cinsiyete göre incelendiği çalışmalara bakıldığında bu sonucun bazı araştırma sonuçları ile tutarlıık gösterirken bazıları ile göstermediği görülmüştür. Karakuş (2017) 60-72 aylık çocukların problem çözme becerilerini incelediği çalışmasında cinsiyete göre anlamlı bir farklıık olmadığı sonucuna ulaşmıştır. Benzer olarak Dereli İman (2013) da Türkiye'deki 6 yaş grubu çocuklar arasında cinsiyetin sosyal problem çözme becerisi açısından bir farklılık göstermediği bulgusuna ulaşmıştır. Yurt içinde yapılan farklı çalışmalarda da bu yönde bulgular elde edilmiş olup (Dereli ,2008; Hamarta, 2007; Şahin, 1999; Yılmaz, 2012) bu durum araştırma sonuçları ile tutarlılık göstermektedir. Arı ve Yaban (2012) ise 911 yaş arası çocuklar ile yürüttükleri çalışmaları sonucunda sosyal problem çözme becerilerinin cinsiyet açısından kızlar lehine farklılık gösterdiği sonucuna ulaşmışlardır. 60-72 aylık çocuklarla yürüttükleri çalışmalarında Yaralı ve Özkan'ın (2016) da benzer bir sonuca ulaştığı görülmektedir. Bu durum çalışma sonuçları ile zıtlık göstermektedir. Özellikle Arı ve Yaban'ın (2012) çalışmalarının yürütüldüğü yaş gruplarının benzer olduğu düşünüldüğünde, bu farklılık daha fazla anlam kazanmaktadır. Bu farklıı̆ın çalışmaya katılan öğrenci sayıları, kullanılan ölçeklerin farkıılığı veya çalışmaya dâhil edilen çocukların sosyo-kültürel farklılıklarından kaynaklanabileceği düşünülmektedir. Bununla birlikte, her iki çalışma arasında geçen zamanın da bununla ilişkili olabileceği düşünülmektedir. Walker, Irving ve Berthelsen (2002) ortalama 62 aylık çocuklarla yürüttükleri çalışmalarında erkeklerin sosyal problem çözme becerilerinin kızlara göre daha zayıf 
olduğunu, erkeklerin daha fazla sözel veya fiziksel şiddet içeren çözümler ürettiklerini belirtmişlerdir. Görüldüğü gibi sosyal problem çözme ile ilgili yürütülen çalışma sonuçları arasında cinsiyet faktörü açısından birtakım farklııklar bulunmaktadır. Bu çalışma sonucunda kızların uygun çözüm seçme ve çözümün sonuçlarını kestirebilme boyutlarında, erkeklerin ise alternatif çözümler üretme boyutunda daha yüksek puan almış olmalarına rağmen, cinsiyetin sosyal problem çözme becerileri üzerinde istatistiksel olarak anlamlı bir farklılık yaratmadığı sonucuna ulaşılmıştır. Sosyal gelişim ve problemleri çözmek konusunda kız çocukları ve erkek çocukların arasında fark olduğunun yaygın bir kanı olduğu söylenebilir. Bu çalışma sonucunda kız çocuklar ve erkek çocukların sosyal problem çözme becerisi arasında belirgin bir fark olmamasında öncelikli olarak örneklem yapısının etkili olabileceği düşünülmektedir. Bununla birlikte; ebeveynlerin bu tür konularda gerek sosyal medya gerekse medya kanalı ile daha bilinçli hale gelmesi, söz konusu nedenlerle anne- baba tutumlarındaki değişmesi gibi sebeplerin de etkili olabileceği düşünülmektedir.

Bu araştırma ile 3. ve 4. sınıf öğrencileri arasında; karşılaşılabilecek bir sosyal problemin çözümü için alternatif çözüm yolları üretme, uygun çözüm yolunu seçme ve çözüm için tercih edilen yöntemin sonuçlarını kestirme boyutlarının her birinde farklılık olduğu görülmüştür. Alternatif çözümler üretme konusunda 3. sınıf öğrencileri lehine bir farklııık görülmüş, uygun çözümü seçme ve seçilen çözümün sonuçlarını kestirebilme basamağında ise 4. sınıf öğrencileri lehine bir farklılık görülmüştür. Alternatif çözüm üretme boyutunda, öğrencilerden istedikleri tüm çözümleri serbestçe yazmaları beklenir. 3. sınıf öğrencilerinin bu aşamada daha yüksek puanlar almasının, bir üst sınıf düzeyindeki öğrencilere göre daha sınırsız düşündükleri ve kendilerini kısıtlamadan düşüncelerini ifade ettikleri şeklinde yorumlanabilir. Uygun çözüm seçme ve çözümün sonuçlarını kestirebilme basamaklarında 4. sınıf lehine olan farklılıkları yaş ile açıklamak mümkündür. Yaş arttıkça bilişsel boyuttaki gelişme ile çocuklarda problem çözme becerisinin geliştiği söylenebilir. Bu durumu destekleyen araştırma sonuçları da bulunmaktadır. Yaban ve Yükselen (2007), korunmaya muhtaç 7-11 yaş arası çocuklarla yürüttükleri çalışmalarında büyük yaş grubu çocukların, problemlere yeni çözüm stratejileri geliştirme konusunda daha başarılı oldukları sonucuna ulaşmışlardır. Benzer olarak Yılmaz ve Tepeli (2013) 60-72 aylık çocuklarla yürütmüş olduğu çalışmasında yaş faktörünün anlamlı bir farklılık yarattığı sonucuna ulaşmıştır. Çam ve Tümkaya (2006), Arı ve Yaban (2012), Bal ve Temel (2014), Bozkurt Yükçü ve Demircioğlu'nun (2017) çalışmaları da yaşın sosyal problem çözme becerisi açısından fark yaratan bir faktör olduğunu desteklemektedir. Sosyal problem çözme becerisi hem sosyal gelişim hem de bilişsel gelişim temelinde şekillenmektedir. Dolayısıyla yaş ile birlikte bu alanlarda meydana gelen gelişimsel ilerlemeyi aynı şekilde sosyal problem çözme becerisinde görmek oldukça anlamlı bir sonuçtur. Bunun yanı sıra çocuğun yaşı ile birlikte yaşamış olduğu sosyal problem çözme deneyimleri de artış göstermektedir. Çocuğun karşılaşmış olduğu her sosyal problem çözme deneyimi bir sonraki problem durumu için temel oluşturması bakımından bu becerinin yaş ile birlikte artması oldukça muhtemel ve istenen bir durumdur (Bozkurt Yükçü ve Demircioğlu, 2017).

Çalışmaya katılan öğrencilerin öğrenim gördükleri okulun konumuna göre sosyal problem çözme becerilerine ilişkin karşılaştırma yapıldığında ise üç boyutta da anlamlı bir farklılık olduğu sonucuna ulaşılmıştır. Her üç boyutta da il ve ilçe merkezindeki çocukların lehine bir farklılaşma vardır. Köylerde yer alan okullarda öğrenim gören öğrencilerin daha az sayıda çözüm ürettikleri, uygun çözüm seçme ve çözümün sonuçlarını kestirme boyutunda daha az puan aldıkları sonucuna ulaşılmıştır. Okulun bulunduğu konum yaşanılan konumla ilişkilidir. Köyler daha küçük yerleşim yerleri olduğu için, burada yaşayan çocukların daha az insanla yakın sosyal etkileşim kurduğu, bunun sonucunda daha az sosyal problemle karşılaşıllyor olması bu sonucun nedenlerinden biri olarak görülebilir. Bununla birlikte köy ile il-ilçe merkezi arasında sosyoekonomik düzey farkı olduğu kabul edilebilir. Araştırma sonuçları göstermiştir ki sosyoekonomik düzey arttıkça sosyal problem çözme becerisi de artmaktadır. Yılmaz (2012) ile Bal ve Temel'in (2014) yapmış oldukları çalışmalar da sosyoekonomik düzey arttıkça sosyal problem çözme becerisinin arttığı görüşünü 
destekler niteliktedir. İlçe ve il merkezindeki okullardaki çocukların sosyal problem çözme becerisinin köydeki okullarda öğrenim gören çocuklardan yüksek olması bu sonuç ile tutarlıdır.

Araştırma sonucunda, ilkokul öğrencilerinin sosyal problem çözme becerilerinin cinsiyete göre farklılaşmadığı, ancak sınıf düzeyi ve öğrenim gördükleri okulların konumuna göre farklılık gösterdiği bulgusuna ulaşılmıştır. Cinsiyete ilişkin bulgular incelendiğinde, anlamlı bir fark olmasa da özellikle uygun çözüm seçme basamağında kızların az bir farkla daha yüksek puanlar aldıkları görülmüştür. Söz konusu farklııkların da en aza indirilmesi bakımından ebeveynlerin ve öğretmenlerin sosyal problem çözme becerilerinin kazandırılmasına yönelik olarak bilgilendirilmelerine ilişkin aile eğitimi programları veya öğretmenlere yönelik eğitimler düzenlenmesinin söz konusu farklılıkları azaltacağı düşünülmektedir. Bununla birlikte, daha farklı özelliklere sahip ve daha büyük örneklemler üzerinde ilkokul dönemindeki çocukların sosyal problem çözme becerilerinin cinsiyete göre incelenmesi bu konuda daha tutarlı sonuçlara ulaşmaya katkı sağlayacaktır. Yine araştırma sonucunda, alternatif çözümler üretme boyutunda 3. Sınıf öğrencilerinin daha yüksek puanlar aldığı bulgusuna ulaşılmıştır. Alternatif çözümler üretebilmek, problemin daha farkı bakış açıları ile anlaşıımasını sağladığından öğretmenlerin tüm öğrencileri üretilebilecek çözüm yelpazesini genişletmek adına cesaretlendirmeleri önem kazanmaktadır. Araştırma sonucunda elde edilen bir diğer bulgu ise, 4. Sınıf öğrencilerinin diğer iki basamakta daha yüksek puanlar aldıklarına yöneliktir. Bu durumda erken sınıflardan başlayarak sosyal içerikli problemlerle öğrencilerin karşılaştırılması, 1. Sınıftan itibaren problem çözme ve karar verme becerilerine odaklanılması problem çözme becerisinin kazandırılması ve geliştirilmesi bakımından önem kazanmaktadır. Son olarak, köydeki okullarda öğrenim gören öğrencilerin sosyal problem çözme becerisine ilişkin tüm basamaklarda diğer öğrencilere göre dezavantajlı olduğu sonucuna ulaşılmıştır. Bu durumda köylerde görev yapmakta olan sınıf öğretmenlerinin sosyal problem çözme becerilerine daha fazla önem vermeleri, derslerini sosyal içerikli problemleri temel alarak yapılandırmaları gerektiği söylenebilir. Ayrıca köylerde görev yapan öğretmenlerin, gerek teknolojiyi kullanarak gerekse başka şekillerde burada yaşayan öğrencileri daha zengin yaşantılarla buluşturmaları gerektiği söylenebilir. İhtiyaç olduğu durumlarda burada görev yapan öğretmenlere yönelik olarak, içeriği sosyal becerileri ve sosyal problem çözme becerilerini kazandırmaya ilişkin uygulanabilecek farklı yaklaşımlardan oluşan eğitim programları uygulanabilir. Elbette gelecekte bu mesleğe adım atacak olan ve çok yüksek intimalle kırsal kesimde görev yapacak olan sınıf öğretmeni adaylarının da sosyal beceri öğretimi açısından donanımlı bir şekilde yetiştirilmesi de önem kazanmaktadır. Bununla birlikte, köylerde öğrenim gören öğrencilerin dâhil edildiği, sosyal problem çözme odaklı deneysel çalışmaların da alana önemli katkılar sağlayacağı düşünülmektedir.

\section{Kaynakça}

Anlıak, ş. ve Dinçer, Ç. (2005). Farklı eğitim yaklaşımları uygulayan okul öncesi eğitim kurumlarına devam eden çocukların kişiler arası problem çözme becerilerinin değerlendirilmesi. Ankara Üniversitesi Eğitim Bilimleri Fakültesi Dergisi, 38 (1), 149-166.

Anooshian, L. J., Pascal, V. U. ve McCreath, H. (1984). Problem mapping before problem solving: Young children's cognitive maps and search strategies in large scale environments. Child Development, 55. DOI: 10.2307/1129929.

Arı, M. ve Yaban, H. (2012). 9-11 yaşındaki çocukların sosyal problem çözme becerilerinde cinsiyet ve yaş farklılıkları. Eğitim ve Bilim, 37 (164), 188-203.

Arı, R. ve Şahin Seçer, Z. (2003). Farklı ana baba tutumlarının çocukların psikososyal temelli problem çözme becerilerine etkisinin incelenmesi. Selçuk Üniversitesi Sosyal Bilimler Enstitüsü Dergisi. 10, 451-464. 
Bal, Ö. ve Temel, Z. F. (2014). Okul öncesi eğitim kurumlarına devam eden 4-6 yaş çocuklarının kişiler arası problem çözme ve bakış açısı alma becerileri arasındaki ilişkinin incelenmesi. Trakya Üniversitesi Eğitim Fakültesi Dergisi, 4(1), 156-169.

Basun, B. (2017). 48-66 Ay Arası Çocukların Sosyal Problem Çözme Becerileri Ve Yaratıcılıklarının Yaşadıkları Bağlam (Kentte Ve Kırsal Bölgede) Açııından Incelenmesi. Yayımlanmamış yüksek lisans tezi. Çukurova Üniversitesi Sosyal Bilimler Enstitüsü.

Berk, L. E. (2013). Bebekler ve Çocuklar: Doğum Öncesinden Orta Çocukluğa. (Çev. N. Işıkoğlu Erdoğan). Ankara: Nobel Yayınevi. (Eserin orijinali 2010'da yayımlandı).

Bozkurt Yükçü, ş. ve Demircioğlu, H. (2017) Okul öncesi dönemdeki çocukların sosyal problem çözme becerilerinin çeşitli değişkenler açısından incelenmesi. Erken Çocukluk Çalışmaları Dergisi, 1(2), 216-238.

Chang, E. C., D'Zurilla T. J. ve Sanna, L. J. (2009). Social problem solving as a mediator of the link between stress and psychological well-being in middle-adulthood. Cognitive Therapy and Research, 33 (1), 33-49.

Çam, S. ve Tümkaya, S. (2006). Üniversite öğrencilerinde kişilerarası problem çözme. Çukurova Üniversitesi Sosyal Bilimler Enstitüsü Dergisi, 15(2), 119-132.

Dereli, E. (2008). Çocuklar için Sosyal Beceri Eğitim Programının 6 Yaş Çocukların Sosyal Problem Çözme Becerilerine Etkisi. Yayımlanmamış Doktora Tezi. Selçuk Üniversitesi Sosyal Bilimler Enstitüsü.

Dereli İman, E. (2013). Çocuklar İçin Sosyal Problem Çözme Ölçeğinin 6 Yaş Grubu iç̧in Türkiye Uyarlaması ve Okul Öncesi Davranış Problemleri ile Sosyal Problem Çözme Becerileri Arasındaki Iliş̧kiler. Kuram ve Uygulamada Eğitim Bilimleri, 13(1), 479-498.

D'Zurilla, T.J. ve Goldfried, M.R. (1971). Problem solving and behavior modification. Journal of Abnormal Psychology, 78, 107-126.

D'Zurilla, T. J. ve Nezu, A. (1982). Social problem-solving in adults. In P. C. Kendall (Eds). Advances in cognitive-behavioral research and therapy (pp. 201-274). New York: Academic Press.

Hamarta, S. (2007). Illköğretim 8. Sınıf Öğrencilerinin Sosyal Problem Çözme Becerilerinin Algılanan Anne-Baba Tutumları Açııından incelenmesi. Yayımlanmamış Yüksek Lisans Tezi. Selçuk Üniversitesi Sosyal Bilimler Enstitüsü.

Karakuş, N. (2017). 60-72 Ay Çocukların Sosyal Problem Çözme Becerilerinin Anne Tutumları Açısından incelenmesi. Yayımlanmamış yüksek lisans tezi. Selçuk Üniversitesi Sosyal Bilimler Enstitüsü. Konya.

Karasar, N. (2016). Bilimsel Araştırma Yöntemi: Kavramlar, Ilkeler ve Teknikler. Ankara: Nobel Yayıncilık.

Kayılı, G. ve Arı, R. (2015). Wally Sosyal Problem Çözme Testi: Geçerlik ve güvenirlik çalışması. Uluslararası Eğitim Bilimleri Dergisi, 3, 51-60.

Kayılı, G. (2015). Sosyal Beceri Eğitimi Programı ile Desteklenmiş Montessori Yönteminin Anaokulu Çocuklarının Duyguları Anlama ve Sosyal Problem Çözme Becerilerine Etkisi. Yayımlanmamış Doktora Tezi. Selçuk Üniversitesi Sosyal Bilimler Enstitüsü. Konya.

Korkut, F. (2002). Lise Öğrencilerinin Problem Çözme Becerileri. Hacettepe Üniversitesi Eğitim Fakültesi Dergisi. 22, 177-184.

Levendosky, A. A., Okun, A. ve Parker, J. G. (1995). Depression and maltreatment as predictor of social competence and social problem-solving skills in school-age children. Journal of Child Abuse and Neglect, 19, 1183-1195.

Lochman, J. E., Lampron, L. B. ve Rabiner, D. L. (1989). Format differences and salience effects in assessment of social problem-solving skills of aggressive and nonaggressive boys. Journal of Clinical Child Psychology, 18, 230-236.

Öğülmüş, S. (2006). Kişilerarası Sorun Çözme Becerileri ve Eğitimi (3. Basım). Ankara: Nobel Yayınları. 
Özaydın, L. (2006). Arkadaşıık Becerilerini Geliştirme Programının Özel Gereksinimi Olan Ve Olmayan Okul Öncesi Çocuklarının Sosyal Etkileşimlerine Etkisi. Yayımlanmamış Doktora Tezi. Ankara Üniversitesi.

Özmen, D. (2013). 5-6 yaş grubu çocukların akran ilişkilerinin sosyal problem çözme becerisi açısından incelenmesi. Yayımlanmamış Doktora Tezi. Selçuk Üniversitesi Sosyal Bilimler Enstitüsü. Konya.

Stevens, A. D. (2009). Social problem-solving and cognitive flexibility: Relations to social skills and problem behavior of at-risk young children. Unpublished Doctoral Thesis. Seattle Pacific University.

Siu, A. M. H. ve Shek, D. T. L. (2010). Social problem solving as a predictor of well-being in adolescents and young adults. Social Indicators Research, 95, 393-406.

Şahin, Z. (1999). Çocukların Psiko-Sosyal Temelli Problem Çözme Becerisinin Karşılaştırmalı Olarak incelenmesi. Yayınlanmamış Yüksek Lisans Tezi. Selçuk Üniversitesi Sosyal Bilimler Enstitüsü.

Takahashi, F., Koseki, S. ve Shimada, H. (2009). Developmental trends in children's aggression and social problem-solving. Journal of Applied Developmental Psychology, 30(3), 265-272. Doi:10.1016/j.appdev.2008.12.007

Topçu Kabasakal, Z., Sağkal, A. S. ve Türnüklü, A. (2015). Barış eğitimi programının öğrencilerin şiddet eğilimleri ve sosyal sorun çözme becerileri üzerindeki etkileri. Eğitim ve Bilim, 40 (182), 43-62.

Uzunkol, E. (2014). Hayat Bilgisi Öğretiminde Uygulanan Değerler Eğitimi Programının Öğrencilerin Özsaygı Düzeyleri, Sosyal Problem Çözme Becerileri Ve Empati Düzeylerine Etkisi. Yayımlanmamış Doktora Tezi. Gazi Üniversitesi. Eğitim Bilimler Enstitüsü.

Uzunkol, E. ve Yel, S. (2016). Hayat bilgisi dersinde uygulanan değer eğitimi programının özsaygı, sosyal problem çözme becerisi ve empati üzerine etkisi. Eğitim ve Bilim, 41 (183), 267-292.

Walker, O.L. ve Henderson, H.A. (2012). Temperament and social problem-solving competence in preschool: Influences on academic skills in early elementary school. Social Development, 21 (4), 761-779.

Walker, S., Irving, K. ve Berthelsen, D. (2002). Gender influences on preschool children's social problem-solving strategies. The Journal of Genetic Psychology, 163(2), 197-209, DOI: 10.1080/00221320209598677.

Warden, D. ve MacKinnon, S. (2003). Prosocial children, bullies and victims: An investigation of their sociometric status, empathy and social problem-solving strategies. British Journal of Developmental Psychology, 21, 367-385.

Yaban, E. H. ve Yükselen, A. (2007). Korunmaya muhtaç yedi-on bir yaş grubundaki çocukların sosyal problem çözme becerilerinin incelenmesi. Journal of Society \& Social Work, 18(1), $49-67$.

Yaralı, K. T. ve Özkan, H. K. (2016). Çocukların (60-72 Aylık) sosyal problem çözme becerileri ile sosyal yetkinlik ve davranış durumları arasındaki ilişkinin incelenmesi. Türkiye Sosyal Araştırmalar Dergisi, (2), 345-361.

Yıldırım, A. ve Şimşek, H. (2005). Sosyal Bilimlerde Nitel Araştırma Yöntemleri (5. Baskı). Ankara: Seçkin Yayıncilık.

Yılmaz, E. (2012). 60-72 Aylık Çocukların Duyguları Anlama Becerilerinin Sosyal Problem Çözme Becerilerine Etkisinin incelenmesi. Yayımlanmamış Yüksek Lisans Tezi. Selçuk Üniversitesi Sosyal Bilimler Enstitüsü.

Yılmaz, E. ve Tepeli, K. (2013). 60-72 aylık çocukların sosyal problem çözme becerilerinin duyguları anlama becerileri açısından incelenmesi. Türkiye Sosyal Araştırmalar Dergisi, 172(172), 117-130. 


\section{Extended Summary}

\section{Purpose}

The aim of this research is to examine the social problem-solving skills of primary school students in terms of gender, grade I and the location of the schools. The study seeks to answer following questions:

1. Do social problem-solving skills differentiate according to sex?

2. Is there a difference in social problem-solving skills of 3rd and 4th grade students?

3. 3- Does the social problem-solving skill vary depending on whether the school is located in a village, suburb or city centre?

\section{Methodology}

Descriptive survey model is for this research as this model aims to describe a situation as it is (Karasar,2010). The population of the study consists of primary school students who are studying in 3rd and 4rd year during the fall semester of 2016-2017 in Province izmit Central District and Körfez District. Stratified sampling is used and the participants of this research are randomly selected 469 students. The "Social Problem-Solving Skills Scale" developed by Uzunkol and Yel (2016) was used as a data collection tool in this research. The scale consists of three short case studies, three questions developed to address the problems in the three cases and an analytical grading scale where the answers to these questions are evaluated. The scale consists of three different sub-scales: producing alternative solutions, choosing the appropriate solution and predicting the outcomes of the solution. The subscale of producing alternative solutions expects students to submit different solution proposals to solve the problem situations in case studies. In the subscale of choosing the appropriate solution, students are expected to choose one of the solutions they have proposed. The selected solution is scored according to five different criteria: uncertain solution, aggressive solution, avoidant solution, indirect solution and direct solution. In the subscale of predicting the outcome of solution, it is expected that the students will be able to predict the positive and negative consequences of the solution they have chosen. Internal consistency coefficients of subscales of producing alternative solutions, choosing the appropriate solution and predicting the outcomes of the solution are respectively $.78, .73$, and .82. The Cronbach Alpha is calculated .73 for all subscales. 469 questionnaires were analysed. Subsequently, Kolmogorov-Smirnov test was used to test whether there was a normal distribution $(p<.05)$. As the data did not show normal distribution, the differences of social problem-solving skills according to sex and class level were examined by Mann Whitney $U$ test and the degree of differentiation according to the school 's location was examined by Kruskal - Wallis test. Then the Mann Whitney $U$ test was conducted again and the reasons and variables of the differences were identified.

\section{Findings}

It was found that the social problem-solving skills of primary school students did not show any significant difference according to gender in all three sub-scales $(p>.05)$. However, girls scored more points in the subscales of choosing the right solution and predicting the outcomes of the solution.

It was found that the social problem-solving skills of primary school students showed a significant difference in all three subscales according to the grade level $(p<.05)$. In the subscale of producing alternative solutions, the third-year students produced more alternative solutions than the fourthyear students. However, when the skill of selecting the appropriate solution is examined, it could be seen that 4 th grade students produce better solutions than the 3rd grade students. The same can be observed for skills of predicting the outcomes of solutions. When social problem-solving 
skills of primary school students were examined according to their location of school, it was concluded that there was a significant difference in three subscales $(p<.05)$. it was seen that the students who were educated in city centres and the suburbs produced more alternative solutions compared to the students in the village. When the skills of predicting the outcome of the solution is examined, it is concluded that there is a difference in favour of the students living in the city centre and suburbs.

\section{Conclusion and Discussion}

This research aimed to investigate the social problem-solving skills of primary school students according to sex, class level and the location of the school. As a result of the research, it was concluded that the social problem-solving skills of 3rd and 4th grade students in primary school did not differ according to gender. When the research looking at social problem-solving skills based on gender were examined, this result echoed in other studies whereas it contradicted with other research. Karakuş (2017) found out that there was no significant difference in problem solving skills of 60-72-month-old children. Similarly, Iman (2013) found that the 6-year-old group did not show a difference in social problem-solving skills among the children. The finding of this research is consistent with the findings of other research carried out in Turkey (Dereli, 2008; Hamarta, 2007; Şahin, 1999; Yılmaz, 2012). On the other hand, Arı and Yaban (2012), Yaralı and Özkan (2016), Walker, Irving and Berthelsen (2002) concluded that social problem-solving skills differ in favour of girls.

This study found that there is a significant difference between thrid and fourth grade students in each of subscale of producing alternative solutions, choosing the appropriate solution path and predicting the outcomes of the solution. There are studies supporting this finding. The research of Yaban and Yükselen (2007), Yılmaz and Tepeli (2013), Çam and Tümkaya (2006), Arı and Yaban (2012), Bal and Temel (2014), Bozkurt Yükçü and Demircioğlu (2017) show that social problemsolving skills increases as the age increases.

When the location of schools istaken into account, a significant difference is noted in all three subscales. The location of the school also signifies where the students live. Villages count as rural areas as they are not densely populated and students have less opportunities for social interaction. Therefore, they face less social problem and this may be one of the reasons that they score lower in social problem-solving skills. 